\title{
No-fault compensation program overdue, experts say
}

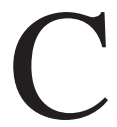

anada and Russia are the only G8 nations without national nofault compensation programs for people injured from vaccines, and according to Canadian vaccine experts, it is high time Canada make its exit from that short but inglorious list.

Canada needs a federal no-fault vaccine-injury compensation program to protect the unfortunate few who suffer adverse reactions to vaccines, according to a new report, Designing $a$ No-Fault Vaccine-Injury Compensation Programme for Canada: Lessons Learned from an International Analysis of Programmes, from the University of Toronto's Munk School of Global Affairs in Ontario (http://webapp .mcis.utoronto.ca/resources/munkpapers /keelan_workingpaper_feb2011.pdf).

When such instances occur now (outside of Quebec, the only province with a no-fault program), injured parties must seek compensation - for lost wages, uninsured medical expenses and rehabilitation services - through legal action. The problem is, they always lose, because vaccine manufactures and health care providers can't be held at fault if they follow best practices.

"If people have an unfortunate reaction to the vaccine, causing permanent or serious injury, they shouldn't have to rely on civil litigation to get compensation," says lead author Jennifer Keelan, assistant professor at the University of Toronto's Dalla Lana School of Public Health. "These injuries will occur despite best practices, and you can't predict the rare people who will have these adverse events."

Not only would a no-fault program benefit individuals who suffer harm, it could help the public in general, says Keelan. The transmission of pathogens in communities drops significantly when vaccination rates hit a certain threshold. This is known as herd immunity. People waffling about whether to get a vaccine would be more likely to get immunized, says Keelan, if they knew an adverse reaction wouldn't cost them financially.

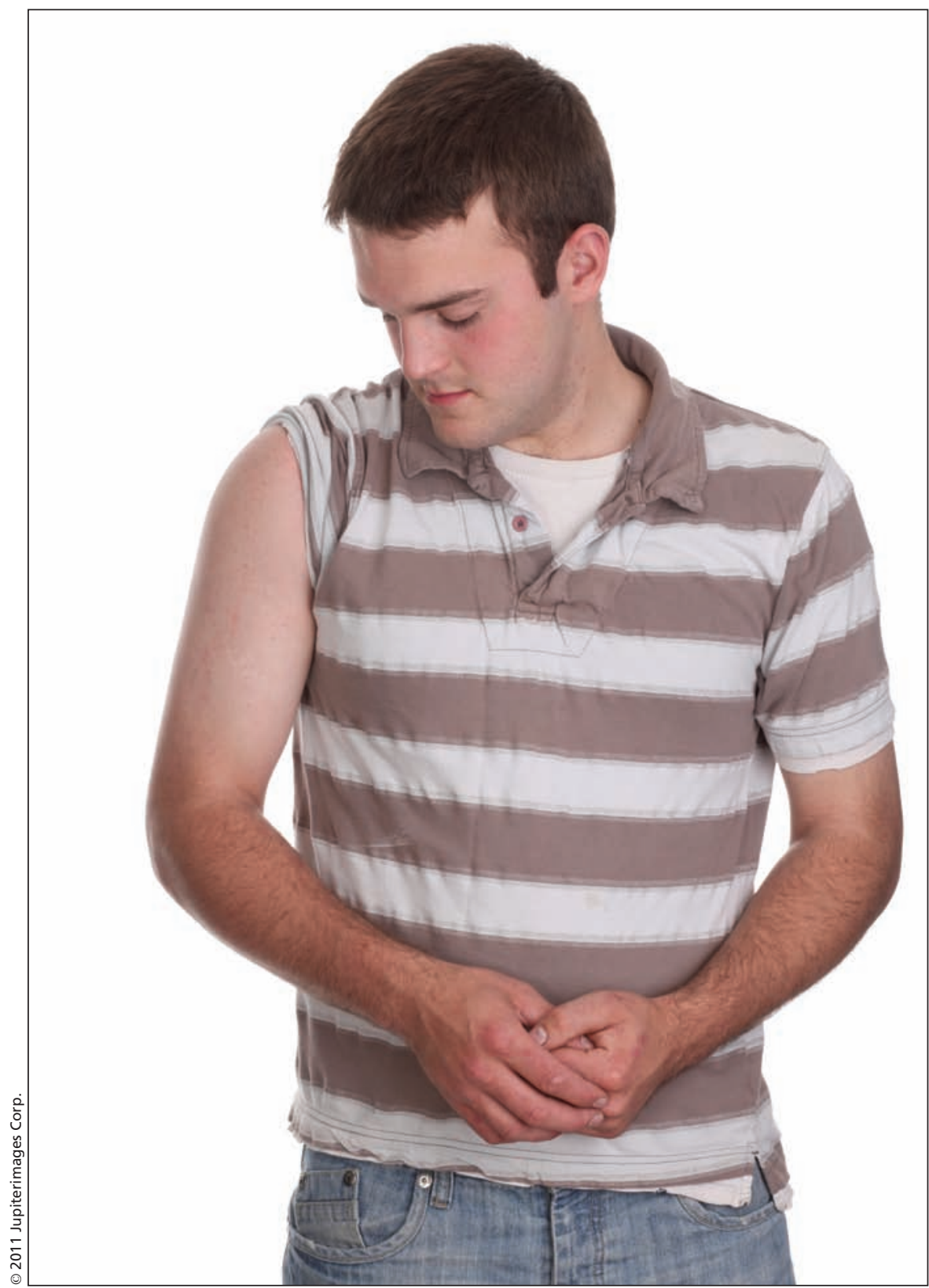

Although millions of Canada receive vaccinations annually, the number who suffer adverse reactions is few, so the cost of a no-fault compensation program would be modest. In Sweden, Taiwan and Norway, no-fault programs are funded by premiums paid by vaccine manufacturers. The United States program is funded by a vaccine tax paid by purchasers, while some countries cover the costs from general government revenues.

People's bank accounts shouldn't suffer, she says, if they make decisions that contribute to public health. "Ethically, it's unacceptable. Many people don't get vaccinated just for themselves; they do it for the good of the community," says Keelan. "Support for immunization is broad in Canada but it is very shallow. It doesn't take very much to unnerve parents who will then choose not to expose their children to vaccines." 
Indeed, knowing that the federal government has your back could only improve vaccination rates, which have been falling in recent years due to growing distrust of the pharmaceutical industry, says Dr. David Scheifele, professor of pediatrics at the University of British Columbia and director of the Vaccine Evaluation Centre, a nonprofit centre for independent vaccine research.

"It would provide a general reassurance to the public from the government that vaccines, while imperfect, are good, and in the rare instances they do something bad, the government will be there to provide assistance," says Scheifele. "It would amount to little more than a token from the government. There is not much potential for huge costs or a substantial number of claims."

Costs would indeed be modest, according to Keelan's report, which states that in Sweden, Taiwan and Norway, no-fault programs are funded by premiums paid by vaccine manufacturers. The United States program is funded by a vaccine tax paid by purchasers, and some countries cover the costs from general government revenues.

"Despite radical differences in approaches, administration and eligibility criteria, data from all four jurisdictions studied shows that the average number of claims and compensation amounts are relatively stable and predictable and represent both an affordable expenditure as part of an overall vaccination immunization programme," the report states. "Still, the predicted number of settlements and the cost of any scheme does depend greatly on eligibility criteria, filing requirements, and the public's knowledge of the programme."

A 2000 paper on compensation for vaccine injuries from the Manitoba Law Reform Commission looked at the costs of programs from various jurisdictions (www.gov.mb.ca/justice/mlrc /reports/104.pdf). Quebec introduced its program in 1985 and between then and 2000, about $\$ 2.7$ million was paid in benefits. The Vaccine Damage Payment Act was passed in the United Kingdom in 1979 and between then and March 2000, compensation in the form of a $£ 40,000$ lump sum payment each was awarded to 896 people.

In the US, the government regularly publishes statistics on the awards given through its National Vaccine Injury Compensation Program (www.hrsa.gov /vaccinecompensation/statistics_report .htm). In 1989, the first year awards were given, six parties received a total of US\$1.4 million. From 1993-2001, the total outlays topped US\$100 million each year, but then began to drop. In 2010 , the program gave a total of US\$89 million to 173 claimants.

However it is paid for, a no-fault sys- tem would also protect the supply of vaccine, says Keelan, because vaccine manufacturers wouldn't have to waste time and resources defending themselves in court. The effect of the antivaccine movement, which publicizes vaccine injuries to further its cause, would also be diminished. "It certainly doesn't allow anti-vaccine activists to throw out martyrs to the cause," says Keelan.

According to Keelan's report, which examines no-fault compensation programs in various jurisdictions around the world, a no-fault approach to handling vaccine would include: recognition that unintended medical injuries are unavoidable; compensation that is modest and based on needs proportionate to the injury; a consistent approach to reviewing cases of injury; involvement from government agencies such as the National Advisory Committee on Immunization or the Public Health Agency of Canada; and a set time frame from date of injury during which claims could be filed.

"There is not a single vaccine expert that we spoke to who didn't agree that this is a gap in policy," says Keelan. "Even the manufacturers, though they disagreed on what the program would look like, agreed that it is a gap in policy." - Roger Collier, CMAJ

CMAJ 2011. DOI:10.1503/cmaj.109-3805 